\title{
Characterization of Lagenaria mild mosaic virus, a New Potexvirus from Bottle Gourd in Myanmar
}

Ok-Kyung Kim and Tadasuke Mizutani, Department of International Agricultural Development, Graduate School of Agriculture, Tokyo University of Agriculture, Tokyo, Japan; Khin Soe, Ministry of Agriculture and Irrigation, Naypyitaw, Myanmar; Key-Woon Lee, Division of Applied Life Sciences, College of Agriculture and Life Sciences, Kyungpook National University, Daegu, Republic of Korea; and Keiko T. Natsuaki, Department of International Agricultural Development, Graduate School of Agriculture, Tokyo University of Agriculture, Tokyo, Japan

\begin{abstract}
Kim, O.-K., Mizutani, T., Soe, K., Lee, K.-W., and Natsuaki, K. T. 2010. Characterization of Lagenaria mild mosaic virus, a new Potexvirus from bottle gourd in Myanmar. Plant Dis. 94:1225-1230.

A putative Potexvirus was detected from bottle gourd (Lagenaria siceraria) showing mosaic and mottle symptoms in Myanmar in 2007. The virus was designated Lagenaria mild mosaic virus (LaMMoV) and was further characterized. In artificial inoculation tests, infectivity of LaMMoV was limited to two families: Chenopodiaceae and Cucurbitaceae. The host range of LaMMoV differs from those of the two cucurbit-infecting potexviruses, Alternanthera mosaic virus (AltMV) and Papaya mosaic virus (PapMV). Sequence analyses of LaMMoV showed that the C-terminal 3,859 nucleotides, excluding the poly-A tail, includes the C-terminal region of an RNA-dependent RNA polymerase (RdRp), a triple gene block (TGB), a coat protein (CP), and a $3^{\prime}$ untranslated region (UTR), all of which are typical of potexviruses. Although LaMMoV is related closely to AltMV and PapMV, its nucleotide sequences differ from those of other previously reported potexviruses. Therefore, we report LaMMoV as a new species of the genus Potexvirus that occurs in the cucurbit bottle gourd.
\end{abstract}

Lagenaria siceraria (Mol.) Stand. is a widely distributed edible and medicinal cucurbit. It is commonly known as bottle gourd, because its fruits are used as bottles or containers (24). A bottle gourd plant with mosaic and mottle symptoms was collected in Myanmar in March 2007. Electron microscope analyses showed that this plant contained two viruses: a putative $P o$ texvirus and a Tobamovirus. The Tobamovirus was identified as Cucumber green mottle mosaic virus (CGMMV) by serological and molecular analyses $(11,12)$.

Viruses in the genus Potexvirus (family Flexiviridae) have filamentous and flexuous virions that are 470 to $580 \mathrm{~nm}$ in length. Each virion contains a single linear molecule of positive-sense RNA encoding five open reading frames (ORFs): an RNAdependent RNA polymerase ( $R d R p)$ gene, three genes known as the triple gene block (TGB), and a coat protein (CP) gene $(2,27)$. The $5^{\prime}$ end has a methylguanosine

Corresponding author: O.-K. Kim E-mail: $70080001 @$ nodai.ac.jp

* The $\boldsymbol{e}$-Xtra logo stands for "electronic extra" and indicates that Figure 1 appears in color in the online edition.

Accepted for publication 14 June 2010.

doi:10.1094/PDIS-02-10-0159

(c) 2010 The American Phytopathological Society cap and the $3^{\prime}$ end has a poly-A tail (15). The ICTV database lists 28 known and 18 tentative member species of the genus Potexvirus (1). These viruses have diverse host species, including cactus (family $\mathrm{Cac}$ taceae), cymbidium (family Orchidaceae), potato (family Solanaceae), and strawberry (family Rosaceae). Although some of these viruses cause mosaic or ringspot symptoms in their hosts, others cause little visible damage (1).

There are a few reports of potexviruses that naturally infect cucurbits. Trichosanthes virus (TV) was isolated in 1988 from Trichosanthes dioica in the United States. TV is a possible potexvirus that is serologically related to Papaya mosaic virus (PapMV) (22,23), which infects Carica papaya and Cucurbita pepo (17). In addition, unidentified potexvirus-like virions were observed in one sample of $\mathrm{Mo}$ mordica charontia by electron microscopy (19). Alternanthera mosaic virus (AltMV) from Alternanthera pungens is a distinct potexvirus that is closely serologically related to PapMV and infects some cucurbit hosts (6). So far, artificial inoculation tests have found 11 potexviruses (excluding AltMV) that infect cucurbits: Clover yellow mosaic virus (ClYMV), Daphne virus $X$ (DVX), Foxtail mosaic virus (FoMV), Hydrangea ringspot virus (HdRSV), Narcissus mosaic virus (NMV), PapMV, Pepino mosaic virus (PepMV), Potato virus $X$ (PVX), Tulip virus $X$
(TVX), White clover mosaic virus (WCIMV), and Viola mottle virus (VMoV, a tentative species in genus Potexvirus) $(3,9,10,15,16,18,21,25)$.

In this paper, we report the occurrence and molecular characterization of a putative Potexvirus isolated from bottle gourd in Myanmar, which we designated Lagenaria mild mosaic virus (LaMMoV). The taxonomic relationship of this virus with other potexviruses is also discussed.

\section{MATERIALS AND METHODS}

Virus isolates and maintenance. CGMMV and LaMMoV were obtained from a naturally infected bottle gourd with mosaic and mottle symptoms in Myanmar in 2007. To separate these two viruses, the sample was inoculated onto Chenopodium quinoa, which is the nonsystemic host of CGMMV (13). LaMMoV systemically infected the host plant, whereas CGMMV was restricted to the inoculated leaves. Therefore, LaMMoV was isolated from upper leaves of the hosts. In backinoculation of bottle gourd, LaMMoV infected the host systemically. The infection was largely symptomless, but some mild mosaic symptoms were visible. The virus was propagated by artificial inoculation for further studies.

Electron microscopy. A drop of sap from the infected plant was placed on a copper grid with carbon-coated collodion film (Nisshin EM Co., Ltd., Tokyo, Japan). The sap was negatively stained with $2 \%$ phosphotungstic acid ( $\mathrm{pH}$ 6.0), and the grid was examined under an electron microscope (H-7600, Hitachi Ltd., Tokyo, Japan).

Host range and symptomatology. To establish the experimental host range of LaMMoV, sap extract was macerated in $0.1 \mathrm{M}$ potassium phosphate buffer $(\mathrm{pH} 7.0)$ (1:10 wt/vol), Carborundum was added as an abrasive, and this mixture was used to inoculate 14 species in six families. Inoculated plants were grown in an incubator at 24 to $27^{\circ} \mathrm{C}$ with a 16 -h light/8-h dark photoperiod, and symptom development was observed for at least 4 weeks after inoculation. In several cases, symptomless or indistinct infections were identified by specific reverse-transcription polymerase chain reaction (RT-PCR). 
Enzyme-linked immunosorbent assay (ELISA). Antisera against PVX and PapMV (Agdia Inc., Elkhart, IN) were used to determine serological relationships with LaMMoV. Antiserum against PVX was provided by T. Maoka (National Agricultural Research Center for Hokkaido Region, Japan). A commercial antiserum kit against CGMMV (Agdia) was used to determine the presence of CGMMV. Absorbance at $405 \mathrm{~nm}$ was measured using a microplate reader (Model 680 Microplate Reader, Bio-Rad, Hercules, CA). Reactions were designated as positive when the absorbance value was three times greater than that of the corresponding control after 30 min incubation with the substrate at room temperature.

RNA extraction, RT-PCR, and $3^{\prime}$ rapid amplification of cDNA ends (RACE). Total RNAs were extracted from bottle gourd infected by LaMMoV using Trizol reagent (Invitrogen Corp., Carlsbad, CA) according to the manufacturer's instructions. Total RNAs were used as a template for first-strand cDNA synthesis and for PCR analyses. The use of degenerate primers specific to the genus Potexvirus (26) resulted in PCR-amplification of a 593-bp fragment, which confirmed the presence of a potexvirus. Then, a pair of specific primers to amplify the partial $\mathrm{CP}$ was designed based on previously reported sequences of AltMV (AY863024, AF080448, AY850928, AY850931, AY850930, and AY566288) and PapMV (D13957, AY017188, and AY017187). First-strand cDNAs were synthesized using a ReverTra Ace - $\alpha$ - kit (TOYOBO Co., Ltd., Osaka, Japan) with AltPap-R (25 pmol) for specific detection. Second-strand cDNAs were synthesized by PCR using TaKaRa Ex Taq PCR buffer (Takara Bio Inc., Otsu, Japan) with amplification primers (Alt-F and AltPap-R, 25 pmol each). The reactions were carried out in a PTC100 Peltier Thermal Cycler (MJ Research, Inc., Waltham, MA) at a PCR annealing temperature of $50^{\circ} \mathrm{C}$. We used several other combinations of PCR primers (Table 1) and obtained specific cDNA amplification products from LaMMoV. To sequence the C-terminal region, a LaMMoV-specific primer (M17PX-3RACE, $10 \mathrm{pmol}$ ) was used in the 3' RACE System for Rapid Amplification of cDNA ends (Invitrogen).

To further examine the relationship between LaMMoV and other potexviruses, and to confirm that $\mathrm{LaMMoV}$ was a new potexvirus, we designed several sets of specific primers (Table 1) and determined the sequences of the $\mathrm{C}$-terminal region of ORF 1 and complete ORFs 2, 3, 4, and 5.

Cloning and sequencing. Amplification products were separated on agarose gels, and each band was then purified from the gel using the Wizard SV Gel and PCR Clean-Up system (Promega Corp., Madison, WI). Purified PCR fragments were ligated into the pGEM T-vector (Promega) following the manufacturer's protocol, and the vector was introduced into competent cells of Escherichia coli JM109 (Takara Bio). Plasmids were isolated from recombinant E. coli using the LaboPass Plasmid Mini kit (Cosmo Genetech Co., Ltd., Seoul, Republic of Korea), and those containing an insert of the expected size were sequenced with an Applied Biosystems 3130/3130xl Genetic Analyzer (Applied Biosystems, Inc., Foster City, CA) using the BigDye Terminator v3.1 Cycle Sequencing Kit (Applied Biosystems).

Sequence analyses. Sequence analyses were conducted using the program on the NCBI homepage (http://www.ncbi.nlm. nih.gov/) and CLC Free Workbench 4.5 software (http://www.clcbio.com/index. php?id=206). For comparison with LaMMoV, Clustal W (version 1.83) was used to align the equivalent sequences of other potexviruses available in the GenBank DNA database (Table 2). Molecular weights of proteins were predicted using the Bioedit sequence alignment editor (version 7.0.9). Pairwise sequence alignments of nucleotide and amino acid sequences were analyzed using MacVector 7.2.2 software (Accelrys Software Inc., San Diego, CA). The phylogenetic tree was constructed from the distance matrix by the neighbor-joining (NJ) method. Reliability of the tree was estimated using bootstrap with 1,000 replicates.

\section{RESULTS}

Epidemiology and morphology. Bottle gourds showing mosaic and mottle symptoms were observed in Myanmar in 2007 (Fig. 1A). Electron microscope analyses showed that sap from these gourds contained 300-nm-long rod-shaped particles that were characteristic of a Tobamovirus. This was identified as CGMMV by ELISA and RT-PCR analyses. The sap also contained filamentous particles approximately $550 \mathrm{~nm}$ in length, which were characteristic of viruses in the genus Potexvirus. The virus was designated as $\mathrm{LaMMoV}$ (Fig. 1B).

Symptomatology and serology. LaM$\mathrm{MoV}$ were separated from CGMMV on upper leaves of an inoculated $C$. quinoa plant by mechanical transmission of a sample containing both viruses. LaMMoV was propagated in bottle gourd. The experimental host range of $\mathrm{LaMMoV}$ is shown in Table 3. Among the tested cucurbit plants, LaMMoV caused mosaic and yellowing in Benincasa hispida, but was asymptomatic in Citrullus lanatus, $\mathrm{Cucu-}$ mis sativus, and Cucurbita pepo. Cucumis melo and Luffa cylindrica were not susceptible host species.

Serological testing demonstrated that LaMMoV was closely related to PapMV, but not to PVX (data not shown).

RT-PCR detection, sequence analyses, and comparison with other potexviruses. We determined the sequence of 3,859 nucleotides (nt) excluding the polyA tail (GenBank accession no. AB546335). This sequence included the coding regions for the C-terminal region of $\mathrm{RdRp}$, the TGB, a CP gene and a $3^{\prime}$ UTR.

The C-terminal region contained the RdRp (ORF 1) gene, which encoded 650 amino acid (aa) residues including a highly conserved RNA replication motif with the consensus sequence 'S/TGEX ${ }_{2}$ TFDANT... GDD'. We also identified a TGB structure composed of overlapping TGB 1 (ORF 2: $690 \mathrm{nt}$ ), TGB 2 (ORF 3: $333 \mathrm{nt}$ ), and TGB 3 (ORF 4: $204 \mathrm{nt}$ ). TGB 1, 2, and 3 encoded polypeptides of 229,110 , and 67 aa, respectively, with calculated molecular weights of approximately 25,538, 11,785,

Table 1. Primers used for detection and sequencing of Lagenaria mild mosaic virus (LaMMoV)

\begin{tabular}{|c|c|c|c|c|}
\hline Primer & Sequence $\left(5^{\prime}\right.$ to $\left.3^{\prime}\right)$ & Target sequences & Position & Amplification regions \\
\hline Potex U1 & ACNNTNGTNYTNCCNVYNGAR & Genus Potexvirus & ORF 1 & Partial ORF 1 \\
\hline M17PX1 & TCAATTGTGGCCCATAAGAGG & LaMMoV & ORF 1 & \\
\hline Potex $5^{b}$ & $\overline{\text { CAYCARCARGCMAARGAYGA }}$ & Genus Potexvirus & ORF 1 & Partial ORF 1 \\
\hline Potex $2 \mathrm{RC}^{\mathrm{b}}$ & AGCATRGCNSCRTCYTG & Genus Potexvirus & ORF 1 & \\
\hline M17PX-TGBf & $\overline{\text { ATGACTTCACAGCCTTCGACC }}$ & LaMMoV & ORF 1 & ORF 2,3 and 4 \\
\hline M17PX-TGBr & TGTGGCGCTCATTGTGACACG & LaMMoV & ORF 5 & \\
\hline M17PX-T1f & $\overline{\text { CTGACAGAAGGAATCTGGAG }}$ & LaMMoV & ORF 2 & Partial ORF 2 \\
\hline M17PX-T1r & CCCGTCAATAAGTCCTCGGTG & LaMMoV & ORF 2 & \\
\hline Alt-F & CCGGGCTTAGGTTTTAGCA & AltMV & ORF 4 & Partial ORF 4 and ORF 5 \\
\hline AltPap-R & TGGCCYTTGGTGATGAA & AltMV and PapMV ${ }^{c}$ & ORF 5 & \\
\hline M17PX-3RACE & TCGCTTCCAACTCСТCСТTCATAAC & LaMMoV & ORF 5 & Partial ORF 5 and $3^{\prime}$ UTR \\
\hline
\end{tabular}

a $\mathrm{ORF}=$ open reading frame. Underlined primers indicate antisense direction.

b Potex 5 and Potex 2RC are from van der Vlugt and Berendsen (26).

c AltMV = Alternanthera mosaic virus; PapMV = Papaya mosaic virus . 
and 7,036 Da, respectively. We identified conserved potexvirus sequences in LaM$\mathrm{MoV}$, such as ' $\mathrm{X}_{2} \mathrm{AGXGKS/T}$ ' (an NTP binding helicase motif in the TGB 1 region), and ' $\mathrm{GDX}_{2} \mathrm{HX}_{2} \mathrm{PXGGXYXDGT}$ $\mathrm{KX}_{3} \mathrm{Y}$ ' in the TGB 2 region. Comparisons between the deduced amino acid sequences of LaMMoV and those of other potexviruses indicated that TGB 1 and TGB 2 had the highest identity with the corresponding TGBs of AltMV, while TGB 3 showed highest identity to PapMV (Table 4). In phylogenetic trees based on TGB 1 and TGB 2, LaMMoV formed a single cluster with AltMV and PapMV. In the tree based on TGB 3, however, the phylogenetic relationship among LaM$\mathrm{MoV}$ and other potexviruses conflicted with their identity percentage, because of the variable lengths and high diversity of the TGB 3 sequences (data not shown). This result suggested that the TGB 3 sequence is too inconsistent to determine relationships among potexviruses.

The CP region of LaMMoV was $627 \mathrm{nt}$ in length, and was predicted to encode a 208 aa protein with an ATG start codon and a TAA stop codon. The $3^{\prime}$ UTR consisted of $119 \mathrm{nt}$ excluding the poly-A tail. The palindromic sequences in this region suggested that it forms stem-loop structures, like those found in other potexviruses. The $\mathrm{CP}$ region of LaMMoV contained the core sequence KFAAFD FFDGV, which is highly conserved in potexviruses.

The CP region of $\mathrm{LaMMoV}$ showed $69 \%$ homology to those of several AltMV isolates at the nucleotide level and $76 \%$ homology with the CP of PapMV (AY017187) at the amino acid level (Table 5). The sequence of the $3^{\prime}$ UTR of LaMMoV showed 67 to $72 \%$ identity with those of AltMV isolates, but only 59\% identity with that of PapMV (D13957) (Table 4).

A phylogenetic tree was constructed to determine the relationships between $\mathrm{LaMMoV}$ and other potexviruses based on the alignments of CP amino acids (Fig. 2). LaMMoV was most closely related to PapMV, and LaMMoV, AltMV, and PapMV formed a single cluster. In addition, the $3^{\prime}$ UTR nucleotide sequence of LaMMoV showed the highest similarity to that of AltMV, and the next highest similarity to that of PapMV (Table 4). These data indicated that $\mathrm{LaMMoV}$ was more closely related to AltMV and PapMV than to the other potexviruses.

\section{DISCUSSION}

We have isolated a new potexvirus, designated as LaMMoV, from a bottle gourd plant in Myanmar, and determined its biological, serological, and molecular characteristics. In artificial inoculation tests, LaMMoV infected plants in only two families: the Chenopodiaceae and Cucurbitaceae. LaMMoV can be distinguished from AltMV, which causes mottle symptoms on tomato, after artificial inoculation. LaMMoV does not infect papaya, which distinguishes it from PapMV. Although LaMMoV showed close serological relationships with PapMV in this study and AltMV was known to be closely related to PapMV (6), the three viruses have differential effects on host plants $(6,8,14)$. LaMMoV has a narrow host range, and many of the infected plants show very mild or no visible symptoms. The original host that showed mosaic and mottle symptoms was infected with both LaMMoV and CGMMV; therefore, the observed symptoms were probably a result of a mixed infection. LaMMoV may cause different symptoms when present as a single infection.

Table 2. Potexvirus sequences used in this study

\begin{tabular}{|c|c|c|}
\hline Virus species & Host and country of origin & $\begin{array}{l}\text { GenBank } \\
\text { accession }\end{array}$ \\
\hline Alternanthera mosaic virus (AltMV) & $\begin{array}{l}\text { Phlox stolonifera; USA } \\
\text { Alternanthera pungens; Australia } \\
\text { Phlox stolonifera; USA } \\
\text { Phlox stolonifera; USA } \\
\text { Portulaca grandiflora; USA } \\
\text { Portulaca } \text { spp.; Italy }\end{array}$ & $\begin{array}{l}\text { AY863024 } \\
\text { AF080448 } \\
\text { AY850928 } \\
\text { AY850931 } \\
\text { AY850930 } \\
\text { AY566288 }\end{array}$ \\
\hline Bamboo mosaic virus (BaMV) & Bambusa oldhamii; Taiwan & D26017 \\
\hline Cactus virus $X(\mathrm{CVX})$ & Hylocereus undatus; Taiwan & AF308158 \\
\hline Cassava common mosaic virus (CsCMV) & Manihot esculenta; Brazil & $\mathrm{U} 23414$ \\
\hline Clover yellow mosaic virus (ClYMV) & Vicia faba; Canada & D29630 \\
\hline Cymbidium mosaic virus (CymMV) & Cattleya sp.; Singapore & U62963 \\
\hline Foxtail mosaic virus (FoMV) & Hordeum sp.; Canada & M62730 \\
\hline Lily virus $X(\mathrm{LVX})$ & Unknown ${ }^{\mathrm{a}}$; Netherlands & AJ633822 \\
\hline Narcissus mosaic virus (NMV) & Narcissus sp.; Netherlands & D13747 \\
\hline Papaya mosaic virus (PapMV) & $\begin{array}{l}\text { Unknown } \\
\text { Cucurbita spp.; Mexico } \\
\text { Carica papaya; Mexico }\end{array}$ & $\begin{array}{l}\text { D13957 } \\
\text { AY017188 } \\
\text { AY017187 }\end{array}$ \\
\hline Pepino mosaic virus (PepMV) & Lycopersicon esculentum; Spain & AF484251 \\
\hline Plantago asiatica mosaic virus (PlAMV) & Plantago asiatica L.; Russia & $\mathrm{Z} 21647$ \\
\hline Potato aucuba mosaic virus (PAMV) & Solanum tuberosum; Canada & S73580 \\
\hline Potato virus $X(\mathrm{PVX})$ & Unknown & X05198 \\
\hline Strawberry mild yellow edge virus (SMYEV) & Unknown & D12517 \\
\hline Tulip virus $X$ (TVX) & Tulipa gesneriana; Japan & AB066288 \\
\hline White clover mosaic virus (WClMV) & Unknown & X06728 \\
\hline
\end{tabular}

${ }^{a}$ Insufficient evidence of natural host species and/or country of origin.

b $3^{\prime}$ Untranslated region ( $3^{\prime}$ UTR) sequences unavailable.
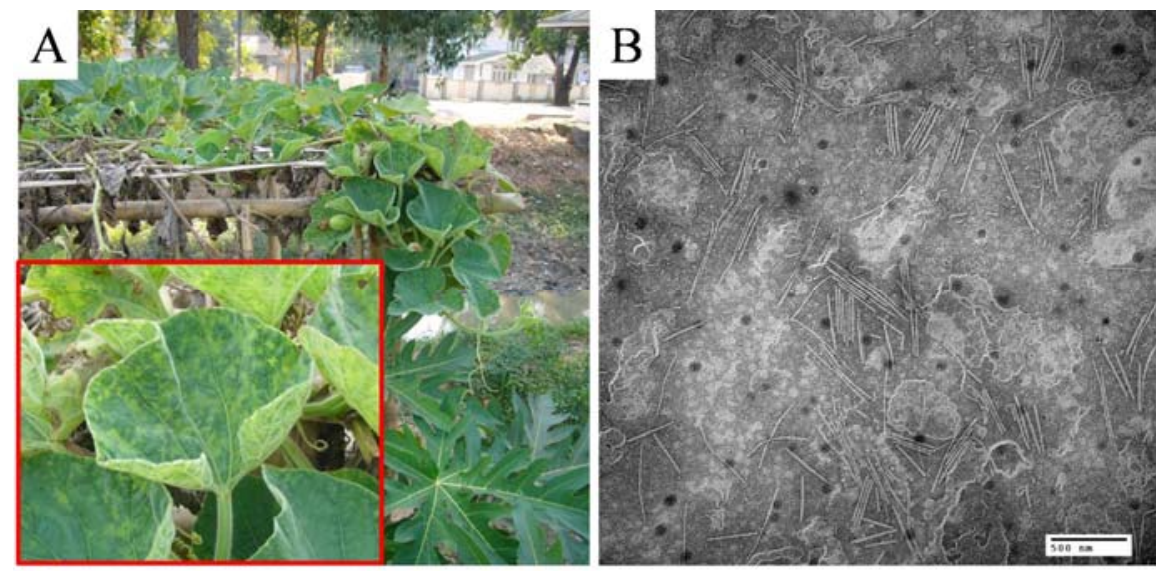

Fig. 1. A, Field symptoms on a diseased bottle gourd caused by Lagenaria mild mosaic virus (LaMMoV) and Cucumber green mottle mosaic virus (CGMMV). B, Transmission electron micrograph showing rod shaped particles of CGMMV approximately $300 \mathrm{~nm}$ in length, and filamentous particles of LaMMoV approximately $550 \mathrm{~nm}$ in length. PapMV but not with As-PVX. In general, distinct species of Potexvirus do not show are a few reports of cross-reactions occur( AltMV was reported to react positively with As-PapMV, leading to a possible misdiagnosis (8). Thus, the positive reaction of LaMMoV against As-PapMV was not sufficient experimental evidence to confirm its identity.

To qualify as a distinct species in the family Flexiviridae, which includes the exting genus Potexvirus, the $\mathrm{CP}$ or replication protein genes of the virus must show less than $72 \%$ identical nucleotides or less than $80 \%$ identical amino acids
LaMMoV reacted positively with Asserological cross-reactions, although there 
compared with their respective genes in other potexviruses $(1,2)$. The $\mathrm{CP}$ gene of LaMMoV showed less than $69 \%$ identity with those of AltMV and PapMV isolates at the nucleotide level, and $75 \%$ identity with that of AltMV and 73 to $76 \%$ identities with those of PapMV isolates at the amino acid level. These results support the finding that LaMMoV is a distinct Potexvirus species. In addition, the sequence data confirm that $\mathrm{LaMMoV}$ is a potexvirus, because it contains several characteristic

Table 3. Comparison of host reactions from infection by Lagenaria mild mosaic virus (LaMMoV), Papaya mosaic virus (PapMV), and Alternanthera mosaic virus (AltMV)

\begin{tabular}{|c|c|c|c|c|c|c|c|c|c|c|}
\hline \multicolumn{4}{|c|}{ Host } & \multirow[b]{2}{*}{ LaMMoV } & \multirow{2}{*}{\multicolumn{2}{|c|}{ PapMV $^{a}$}} & \multirow{2}{*}{\multicolumn{2}{|c|}{ AltMV $^{b}$}} & \multirow{2}{*}{\multicolumn{2}{|c|}{ AltMVc }} \\
\hline Family & Spe & & & & & & & & & \\
\hline \multirow{4}{*}{$\begin{array}{l}\text { Amaranthaceae } \\
\text { Caricaceae } \\
\text { Chenopodiaceae }\end{array}$} & \multicolumn{3}{|c|}{ Spinacia oleracea } & $-\mathrm{d}$ & \multicolumn{2}{|c|}{$\mathrm{S} /+$} & \multicolumn{2}{|c|}{ S/mosaic } & \multicolumn{2}{|c|}{ S/necrotic fleck, leaf curl } \\
\hline & \multicolumn{3}{|c|}{ Carica papaya } & - & \multicolumn{2}{|c|}{ S/mottle, mosaic } & \multicolumn{2}{|c|}{-} & \multicolumn{2}{|c|}{ nt } \\
\hline & \multicolumn{3}{|c|}{ Chenopodium amaranticolor } & $\mathrm{S} /+$ & \multicolumn{2}{|c|}{ S/mottle, mosaic } & \multicolumn{2}{|c|}{ S/mosaic } & \multicolumn{2}{|c|}{ nt } \\
\hline & \multicolumn{3}{|c|}{ Chenopodium quinoa } & $\mathrm{S} /+$ & \multicolumn{2}{|c|}{ S/mottle, mosaic } & \multicolumn{2}{|c|}{ S/interveinal yellowing } & \multicolumn{2}{|c|}{ L/necrotic } \\
\hline Cucurbitaceae & \multicolumn{3}{|c|}{ Benincasa hispida } & S/mosaic, yellowing & \multicolumn{2}{|c|}{ nt } & \multicolumn{2}{|c|}{ nt } & \multicolumn{2}{|c|}{ nt } \\
\hline & Citrul & inatu & & $\mathrm{S} /+$ & & & & & & \\
\hline & Cucun & elo & & - & & & & & & \\
\hline & Cucun & ativus & & $\mathrm{S} /+$ & & & & & & \\
\hline & Cucur & реро & & $\mathrm{S} /+$ & & & & & & \\
\hline & Lagen & sicer & & $\mathrm{S} /+$, mild mosaic & & & & & & \\
\hline & Luffa & drica & & - & & & & & & \\
\hline Fabaceae & Vicia & & & - & & & & & $\mathrm{S} / \mathrm{c}$ & c fleck \\
\hline Solanaceae & Solant & cope & & - & & & & & $\mathrm{S} / \mathrm{mil}$ & , leaf curl \\
\hline & Nicoti & benth & & - & & & S/mosaic, & epinasty & $\mathrm{S} / \mathrm{m}$ & rugosity \\
\hline $\begin{array}{l}\text { a Symptoms of } \mathrm{F} \\
\text { b Symptoms of } \\
\text { c Symptoms of } A \\
\text { d S denotes syst } \\
\text { leaf: - = no inf }\end{array}$ & $\begin{array}{l}\text { PapMV infe } \\
\text { AltMV infec } \\
\text { AltMV infec } \\
\text { temic infecti } \\
\text { fection, }+=\end{array}$ & $\begin{array}{l}\text { dap } \\
\text { dapt } \\
\text { dapt } \\
\text { the }\end{array}$ & $\begin{array}{l}\text { eeri } \\
\text { amr } \\
\text { wed }\end{array}$ & $\begin{array}{l}\text { ret and Jeffrey (14). } \\
\text { g and Thomas (6). } \\
\text { ond et al. ( } 8 \text { ). } \\
\text { by symptom (if visibl } \\
=\text { not tested. }\end{array}$ & $\mathrm{o}$ & $\mathrm{L}$ & otes loca & follow & y syn & inoculated \\
\hline Virus & GenBank & & & TGB 2 & & & SB 3 & & & $\mathbf{3}^{\prime} \mathbf{U T R}^{\mathbf{b}}$ \\
\hline species & accession & aa & nt & aa & nt & aa & nt & aa & nt & nt \\
\hline AltMV & AY863024 & $\underline{50}$ & 52 & $\underline{53}$ & 56 & 28 & $\underline{50}$ & $\underline{75}$ & 69 & 68 \\
\hline BaMV & D26017 & $\overline{36}$ & 43 & $\overline{31}$ & 42 & 13 & $\overline{48}$ & $\overline{22}$ & $\overline{32}$ & $\overline{27}$ \\
\hline CVX & AF308158 & 45 & 53 & 37 & 43 & 26 & 39 & 42 & 50 & 24 \\
\hline CsCMV & $\mathrm{U} 23414$ & 42 & $\underline{55}$ & 33 & 41 & 18 & 25 & 41 & 45 & 23 \\
\hline ClYMV & D29630 & 43 & $\overline{51}$ & 41 & 49 & 8 & 23 & 32 & 39 & 20 \\
\hline CymMV & U62963 & 24 & 35 & 31 & 43 & 13 & 21 & 29 & 41 & 30 \\
\hline FoMV & M62730 & 36 & 44 & 36 & 40 & 17 & 28 & 23 & 33 & 25 \\
\hline LVX & AJ633822 & 33 & 41 & 35 & 43 & 11 & 28 & 36 & 41 & 24 \\
\hline NMV & D13747 & 27 & 35 & 26 & 35 & 12 & 24 & 23 & 37 & 8 \\
\hline PapMV & D13957 & 45 & 52 & 52 & $\underline{58}$ & 39 & 48 & 73 & 67 & 59 \\
\hline PepMV & AF484251 & 24 & 37 & 25 & $\overline{37}$ & $\overline{13}$ & 27 & 27 & 35 & 18 \\
\hline PIAMV & Z21647 & 44 & 52 & 37 & 43 & 9 & 16 & 44 & 49 & 20 \\
\hline PAMV & S73580 & 22 & 37 & 26 & 41 & 12 & 25 & 23 & 34 & 27 \\
\hline PVX & X05198 & 36 & 44 & 34 & 45 & 14 & 29 & 32 & 42 & 16 \\
\hline SMYEV & D12517 & 28 & 38 & 37 & 41 & 14 & 25 & 30 & 38 & 25 \\
\hline TVX & AB066288 & 46 & 51 & 36 & 41 & 8 & 22 & 46 & 52 & 19 \\
\hline WCIMV & X06728 & 30 & 41 & 31 & 37 & 16 & 25 & 31 & 40 & 28 \\
\hline
\end{tabular}

${ }^{a}$ Underlined figures indicate the highest identity percentages between LaMMoV and other Potexviruses for each region.

${ }^{\mathrm{b}} \mathrm{TGB}=$ triple gene block; $\mathrm{CP}=$ coat protein; $3^{\prime} \mathrm{UTR}=3^{\prime}$ untranslated region.

Table 5. Identity of nucleotides (shaded) and amino acids (nonshaded) based on coat protein sequences ${ }^{\mathrm{a}}$

\begin{tabular}{|c|c|c|c|c|c|c|c|c|c|c|c|}
\hline & \multirow[b]{2}{*}{ PVX } & \multicolumn{6}{|c|}{ AltMV } & \multicolumn{3}{|c|}{ PapMV } & \multirow[b]{2}{*}{ LaMMoV } \\
\hline & & AY850931 & AY850928 & AY863024 & AF080448 & AY850930 & AY566288 & D13957 & AY017188 & AY017187 & \\
\hline PVX & & 33 & 33 & 33 & 33 & 34 & 34 & 33 & 34 & 34 & 33 \\
\hline \multicolumn{12}{|l|}{ AltMV } \\
\hline AY850931 & 39 & & 100 & 97 & 97 & 95 & 95 & 73 & 74 & 75 & 75 \\
\hline AY850928 & 39 & 99 & & 97 & 97 & 95 & 95 & 73 & 74 & 75 & 75 \\
\hline AY863024 & 41 & 96 & 96 & & 97 & 95 & 94 & 73 & 74 & 75 & 75 \\
\hline AF080448 & 39 & 93 & 93 & 93 & & 98 & 97 & 73 & 75 & 76 & 75 \\
\hline AY850930 & 40 & 93 & 93 & 94 & 94 & & 99 & 73 & 74 & 75 & 75 \\
\hline AY566288 & 40 & 94 & 93 & 95 & 94 & 97 & & 72 & 73 & 74 & 75 \\
\hline \multicolumn{12}{|l|}{ PapMV } \\
\hline D13957 & 40 & 67 & 66 & 66 & 67 & 66 & 67 & & 89 & 89 & 73 \\
\hline AY017188 & 40 & 66 & 66 & 67 & 68 & 66 & 67 & 78 & & 99 & 75 \\
\hline AY017187 & 40 & 67 & 67 & 67 & 68 & 67 & 67 & 77 & 93 & & 76 \\
\hline LaMMoV & 40 & 69 & 69 & 69 & 68 & 69 & 69 & 67 & 66 & 66 & \\
\hline
\end{tabular}

\footnotetext{
${ }^{a}$ Pairwise analysis performed with Alternanthera mosaic virus (AltMV) and Papaya mosaic virus (PapMV) isolates (most closely related to Lagenaria mild
} mosaic virus [LaMMoV]; AB546335), and Potato virus X (PVX; X05198, only distantly related to LaMMoV). 
conserved regions. Geering and Thomas (6) first identified the core region of $\mathrm{CP}$ in potexviruses, which is equivalent to amino acid residues $\mathrm{A}_{54}$ to $\mathrm{E}_{178}$ in PVX strain $\mathrm{XA}$. Based on those findings, we aligned the core region of the $\mathrm{CP}$ to construct a phylogenetic tree. The result was consistent with those obtained when the $\mathrm{CP}$ amino acids were compared (data not shown). Accordingly, our results also suggest that the core region of the $\mathrm{CP}$ is a useful marker for genetic relationships among potexviruses.

The 3' UTR of single-stranded positivesense RNA viruses has essential roles in viral RNA amplification, such as stabilization of viral RNA and enhancement of translation of viral genes $(4,7)$. Secondary or tertiary structures of the $3^{\prime}$ UTR of a few potexviruses have been characterized, and include such elements as stem-loop structures, a hexanucleotide motif (5'ACATAA), and a U-rich region, the latter two of which are required for RNA accumulation in PVX (20). The ability of WCIMV to infect host plants was affected by decreasing the length of the poly-A tail and mutating the hexanucleotide motif $\left(5^{\prime}\right.$ nylation signal (7). A hexanucleotide motif (5'-ACTTAA) in CIYMV is essential for accumulation of progeny RNA (28), and stem structures of the Bamboo mosaic virus (BaMV) play an important role in the initiation of minus-strand RNA synthesis (4). In the 3' UTR of LaMMoV RNA, we AATAAA), which is a putative polyade-

found hexanucleotide motif-like sequences ( $5^{\prime}$-ACCTAC) located 80 nucleotides downstream from the stop codon of the $\mathrm{CP}$ gene. Hexanucleotide sequences in the form of $5^{\prime}$-ACTTAA or 5'ACCTAA have been found in almost all potexviruses, and similar sequences have been reported in PVX (5'-ACATAA) and PapMV (5'-ACTTAC) (20,28). Taken together, these studies identified conserved residues at position 1 (A), 2 (C), 4 (T), and 5 (A), although White et al. (28) showed that a nucleotide substitution at position 5 did not affect accumulation of viral RNA. Thus, it is possible that the $5^{\prime}$ ACCTAC sequence containing at least four conserved residues may be associated with synthesis of viral RNA. In contrast, the 3' UTR of LaMMoV RNA did not contain a polyadenylation signal. In light of this, a structural analysis of the $3^{\prime}$ UTR of LaMMoV RNA should be carried out to identify sequences associated with RNA accumulation, and to compare LaMMoV with other potexviruses. Information obtained from such studies will be useful for designing effective control strategies.

In summary, our analyses indicated that LaMMoV is closely related to, but distinct from, AltMV and PapMV. Our results also suggested that these three viruses may share common ancestry. To our knowledge, this is the first report of sequence information for a cucurbit-infecting potexvirus. Sequence data and serological

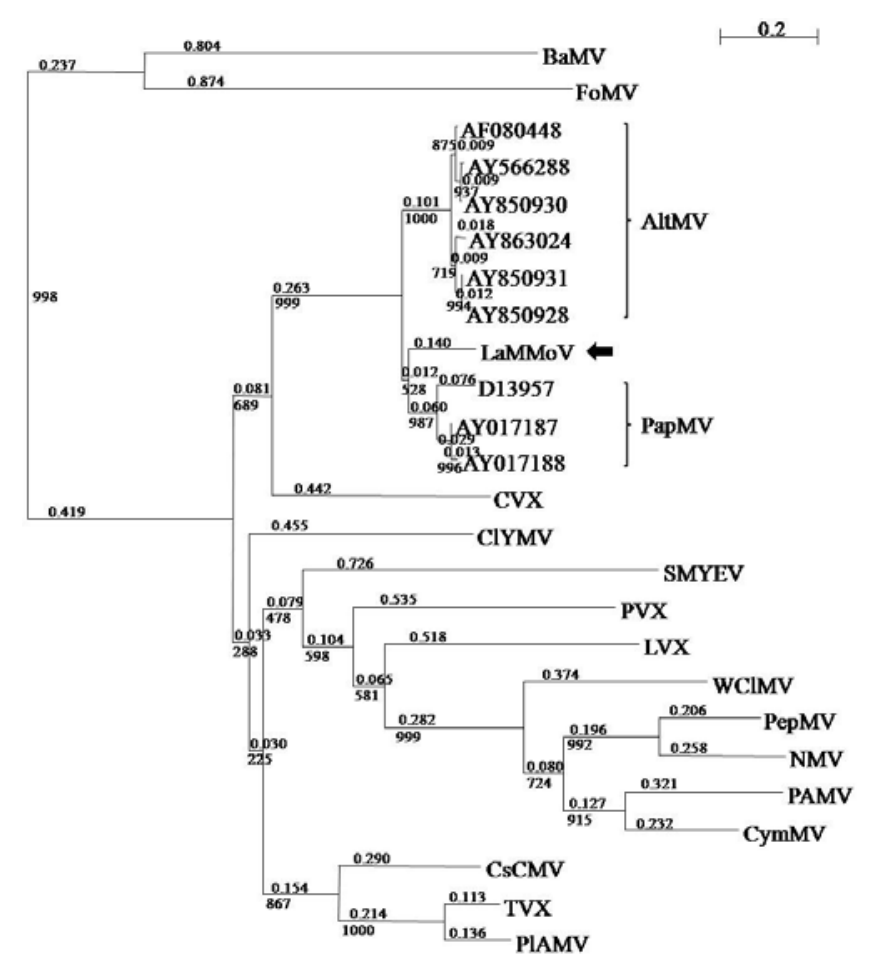

Fig. 2. Phylogenetic relationships among potexviruses based on coat protein amino acid sequences (Table 1). Tree was constructed using the neighbor-joining method as implemented in Clustal W (version 1.83). Numbers represent bootstrap values with 1,000 replications. Value on the scale bar represents 0.2 nucleotide substitutions per site. Virus species are designated by their abbreviation. Compound isolates were used for Alternanthera mosaic virus (AltMV) and Papaya mosaic virus (PapMV). GenBank accession numbers are shown. analyses indicated that $\mathrm{LaMMoV}$ is a new species of the genus Potexvirus.

\section{ACKNOWLEDGMENTS}

We thank Y. Yaguchi (Tokyo University of Agriculture, Japan) for assistance with electron microscopy, and T. Maoka (National Agricultural Research Center for Hokkaido Region, Japan) for providing the PVX antiserum.

\section{LITERATURE CITED}

1. Adams, M. J., Accotto, G. P., Agranovsky, A. A., Bar-Joseph, M., Boscia, D., Brunt, A. A., Candresse, T., Coutts, R. H. A., Dolja, V. V., Falk, B. W., Foster, G. D., Gonsalves, D., Jelkmann, W., Karasev, A., Martelli, G. P., Mawassi, M., Milne, R. G., Minafra, A., Namba, S., Rowhani, A., Vetten, H. J., Vishnichenko, V. K., Wisler, G. C., Yoshikawa, N., and Zavriev, S. K. 2005. Genus Potexvirus. Pages 1091-1095 in: Virus Taxonomy: Classification and Nomenclature of Viruses: Eighth Report of the International Committee on Taxonomy of Viruses. C. M. Fauquet, M. A. Mayo, J. Maniloff, U. Desselberger, and L. A. Ball, eds. Elsevier/Academic Press, San Diego, CA.

2. Adams, M. J., Antoniw, J. F., Bar-Joseph, M., Brunt, A. A., Candresse, T., Foster, G. D., Martelli, G. P., Milne, R. G., and Fauquet, C. M. 2004. The new plant virus family Flexiviridae and assessment of molecular criteria for species demarcation. Arch. Virol. 149:1045-1060.

3. Brierley, P., and Lorentz, P. 1957. Hydrangea ringspot virus, the probable cause of "runningout" of the florists' hydrangea. Phytopathology 47:39-43.

4. Cheng, C.-P., and Tsai, C.-H. 1999. Structural and functional analysis of the $3^{\prime}$ untranslated region of Bamboo mosaic potexvirus genomic RNA. J. Mol. Biol. 288:555-565.

5. Currier, S., and Lockhart, B. E. L. 1996. Characterization of a potexvirus infecting Hosta spp. Plant Dis. 80:1040-1043.

6. Geering, A. D. W., and Thomas, J. E. 1999 Characterisation of a virus from Australia that is closely related to papaya mosaic potexvirus. Arch. Virol. 144:577-592.

7. Guilford, P. J., Beck, D. L., and Forster, R. L. S. 1991. Influence of the poly (A) tail and putative polyadenylation signal on the infectivity of white clover mosaic potexvirus. Virology 182:61-67.

8. Hammond, J., Reinsel, M. D., and MaroonLango, C. J. 2006. Identification and full sequence of an isolate of Alternanthera mosaic potexvirus infecting Phlox stolonifera. Arch. Virol. 151:477-493.

9. Johnson, F. 1942. The complex nature of white-clover mosaic. Phytopathology 32:103116.

10. Jones, R. A. C. 1980. Pepino mosaic virus, a new potexvirus from pepino (Solanum muricatum). Ann. Appl. Biol. 94:61-68.

11. Kim, O. K., Mizutani, T., Khin, S., Lee, K. W. and Natsuaki, K. T. 2008. Detection and identification of cucurbit viruses in Myanmar. International Union of Microbiological Societies (IUMS), Istanbul, Turkey. p. 182.

12. Kim, O. K., Mizutani, T., Natsuaki, K. T., Lee, K. W., and Khin, S. 2010. First report and genetic variability of Cucumber green mottle mosaic virus occurring on bottle gourd in Myanmar. J. Phytopathol. 158:572-575.

13. Kim, S. M., Lee, J. M., Yim, K. O., Oh, M. H., Park, J. W., and Kim, K. H. 2003. Nucleotides sequences of two Korean isolates of cucumber green mottle mosaic virus. Mol. Cells 16:407412.

14. Margaret, N. S., and Jeffrey, W. D. 1987. Host ranges, symptoms and amino acid compositions of eight potexvirus. Ann. Appl. Biol. 110:213-219. 
15. Mentaberry, A., and Orman, B. 1995. Potexviruses. Pages 19-33 in: Pathogenesis and Host Specificity in Plant Diseases. Histopathological, biochemical, genetic and molecular bases. Vol. 3: Viruses and Viroids. R. P. Singh, U. S. Singh, and K. Kohmoto, eds. Elsevier Science Ltd., Kidlington, UK

16. Mowat, W. P. 1982. Pathology and properties of tulip virus $X$, a new potexvirus. Ann. Appl. Biol. 101:51-63.

17. Noa-Carrazana, J. C., and Silva-Rosales, L. 2001. First report of a Mexican isolate of $\mathrm{Pa}$ paya mosaic virus in papaya (Carica papaya) and pumpkin (Cucurbita pepo). Plant Dis. 85:558.

18. Paulsen, A. Q., and Niblett, C. L. 1977. Purification and properties of foxtail mosaic virus. Phytopathology 67:1346-1351.

19. Pearson, M. N., and Liyanage, A. de S. 1997. Records of cucurbit viruses infecting vegetable crops in Western Samoa. Aust. Plant Pathol.
26:188-191.

20. Pillai-Nair, N., Kim, K.-H., and Hemenway, C. 2003. Cis-acting regulatory elements in the potato virus $X 3^{\prime}$ non-translated region differentially affect minus-strand and plusstrand RNA accumulation. J. Mol. Biol. 326:701-720.

21. Purcifull, D. E., and Edwardson, J. R. 1981. Potexviruses. Pages 627-693 in: Handbook of Plant Virus Infections: Comparative Diagnosis. E. Kurstak, eds. Elsevier/North-Holland Biomedical Press, Amsterdam, Netherlands.

22. Purcifull, D. E., Simone, G. W., Baker, C. A., and Hiebert, E. 1988. Immunodiffusion tests for six viruses that infect cucurbits in Florida. Proc. Fla. State Hortic. Soc. 101:400-403.

23. Purcifull, D. E., Simone, G. W., Hiebert, E., Petersen, M. A., Webb, S. E., Kucharek, T. A., Beckham, K. A., and Crawford, W. E. 1999. Some properties of a possible potexvirus isolated from Trichosanthes dioptera (Cucurbita- ceae) in Florida. (Abstr.) Phytopathology 89:S62.

24. Robinson, R. W., and Decker-Walters, D. S. 1997. Cucurbits. CAB International, Wallingford, UK.

25. Short, M. N., and Davies, J. W. 1987. Host ranges, symptoms and amino acid compositions of eight potexviruses. Ann. Appl. Biol. 110:213-219.

26. van der Vlugt, R. A. A., and Berendsen, M 2002. Development of a general potexvirus detection method. Eur. J. Plant Pathol. 108:367371.

27. Verchot-Lubicz, J., Ye, C.-M., and Bamunusinghe, D. 2007. Molecular biology of potexviruses: Recent advances. J. Gen. Virol. 88:16431655.

28. White, K. A., Bancroft, J. B., and Mackie, G. A. 1992. Mutagenesis of a hexanucleotide sequence conserved in potexvirus RNAs. Virology 189:817-820. 